$\mathrm{JMB}$

1,2

Received 12 October 2021

Revised 16 October 2021 Accepted 16 October 2021

\section{Heuristic biases and investment decisions: multiple mediation mechanisms of risk tolerance and financial literacy-a survey at the Tanzania stock market}

\author{
Pendo Shukrani Kasoga \\ Department of Accounting and Finance, The University of Dodoma, \\ Dodoma, United Republic of Tanzania
}

\begin{abstract}
Purpose - The purpose of this research is to examine the effect of heuristic biases on investment decisions through multiple mediation mechanisms of risk tolerance and financial literacy in the Tanzanian stock market. Design/methodology/approach - A sample of 316 individual investors in the Tanzanian stock market was obtained through questionnaires. The data were analyzed using structural equation modeling (SEM).

Findings - The findings show that financial literacy mediates insignificantly the effects of overconfidence, availability, anchoring and representativeness heuristics on investment decisions. Further, financial literacy does not influence the effect of risk tolerance and investment decisions. Risk tolerance is confirmed as a positive mediator of overconfidence, availability, anchoring and representativeness heuristics in investment decisions. Also, the study shows that overconfidence exerts a stronger influence on investment decisions, followed by availability, representativeness, risk tolerance, anchoring and financial literacy.

Research limitations/implications - The study deals with real investors. Therefore, it uses fewer items to measure the constructs in order to avoid respondent bias. Further research could examine the effects of heuristic biases on investment decisions by adding or modifying the items of particular constructs and studying institutional investors.

Practical implications - The findings can help individual investors to analyze and evaluate their behavior toward stock selection. Securities institutions can use this research to understand investors' behavior, evaluate future market trends and provide advice to the investors.

Originality/value - Previous studies have examined the impact of heuristics on the investment decisions of individual investors. The unique empirical analysis developed in this paper is that it examines the multiple mediation mechanisms of risk tolerance and financial literacy with respect to heuristic biases and investment decisions in the Tanzanian stock market.
\end{abstract}

Keywords Behavioral finance, Risk tolerance, Financial literacy, Heuristics biases, Investment decision, Individual investor

Paper type Research paper

\section{Introduction}

Whereas around the world, stock markets are being used to help companies and investors raise capital and expand their enterprises, the stock market in Tanzania is not strong enough compared to its peers as a source of capital for financial investors (Shayo, 2020). Ziorklui (2001) uncovered that the stock market in Tanzania is influenced by different components, among

(C) Pendo Shukrani Kasoga. Published in Journal of Money and Business. Published by Emerald Publishing Limited. This article is published under the Creative Commons Attribution (CC BY 4.0) licence. Anyone may reproduce, distribute, translate and create derivative works of this article (for both commercial and non-commercial purposes), subject to full attribution to the original publication and authors. The full terms of this licence may be seen at http://creativecommons.org/licences/by/4.0/ legalcode 
them are risk perception and financial literacy. However, the study did not examine the effect of heuristic biases on investment decisions through risk tolerance and financial literacy.

In contrast to modern portfolio theory and the efficient market hypothesis that investors are rational, behavioral finance argues that people make irrational financial decisions (Parveen et al., 2020). Since risk-taking is a common practice for investors, heuristic biases alone cannot describe investors' decision-making process; risk perception must be considered (Ishfaq et al., 2020). Moreover, there is an agreement that people who are more financially literate tend to be more tolerant of risk (Grable and Roszkowski, 2008).

Previous research has built up the effect of heuristic biases on individual and institutional investors' investment decisions. However, most researchers look at the direct relationship between heuristic biases and investment decisions (Raheja and Dhiman, 2020; Rasool and Ullah, 2019), paying less consideration to the multiple mediation mechanisms of risk tolerance and financial literacy that affect heuristic biases and investment decisions. To address this gap, this study examines the multiple mediation mechanisms of risk tolerance and financial literacy that assist to clarify these relationships. By examining these intervention components, the study gains a stronger understanding of processes (Abdin et al., 2017), clarifies the nature of the relationship between heuristics and investment decisions and addresses the causality question (Peloza, 2009). Also, understanding the mediation mechanisms enhances practical applications and provides the level of detail required by financial advisors and investors, which enables better management of investment decisions (Peloza, 2009). Besides, past studies have found out that heuristic biases vary from nation to nation (Pompian, 2011). Thus, there is a need to explore the multiple mediation mechanisms of risk tolerance and financial literacy as related to heuristic biases and investment decisions.

This study appears to be relevant to emerging markets, such as Tanzania, because these heuristic biases could have an impact on investors' gains and losses. For instance, the overconfidence bias can lead investors to pay a lot of brokerage costs and make them more vulnerable to high misfortunes because they trade a lot without having sufficient financial knowledge (Parveen et al., 2020). The representativeness bias may result in purchasing overpriced stocks because of the tendency to associate new events with known events (Waweru et al., 2008). For the most part, deviation from the correct and optimal investment decisions in stock exchanges is one of the most critical issues and it regularly leads to poor returns for investors (Jaiyeoba et al., 2020; Waweru et al., 2008). Hence, the findings of the study will offer assistance to investors in understanding the effect of investment decisions they make based on heuristic biases, attitudes toward risk and financial literacy within Tanzanian's socio-cultural context. The findings of this study will also offer assistance to policymakers to take suitable measures to train future investors to manage the emerging stock market of Tanzania successfully and smoothly.

\section{Literature review}

\subsection{Heuristic theory}

In psychology, heuristic biases are mental shortcuts learned by experience, which clarify how investors make decisions and solve issues, especially when confronting complex problems with incomplete information (Ritter, 1988). Heuristics are valuable in the event that time is constrained and information is limited (Tversky and Kahneman, 1974). (Tversky and Kahneman (1974) introduced three heuristics which could be utilized by individual investors in their decision-making: anchoring, availability and representativeness. Afterward, Waweru et al. (2008) added overconfidence to the list.

Overconfidence bias occurs when individuals overestimate their ability, knowledge and skills and consider themselves as keen participants and believe that they can earn a higher return (Asad et al. (2018; Hvide, 2002).

\section{Heuristic biases and investment decision}


$\mathrm{JMB}$

1,2

104

Representativeness is referred to as the rule of thumb, by which people assign the likelihood of that event being more representative and similar to its population (Tversky and Kahneman, 1974). In representativeness heuristics, investors purchase hot stocks and avoid stocks that have performed poorly in the recent past (Waweru et al., 2008).

Availability refers to the fact that a decision maker depends upon easily available information rather than all relevant data (Tversky and Kahneman, 1974). The availability bias contributes to understanding the phenomena reported in stock markets of overreaction of stock prices to a series of good or bad news (Pompian, 2011). Shukla et al. (2020) showed that very frequently participants in the stock market predictably overreact to new information, making more than effect on a security's price. They added that investors prefer to purchase local stock rather than international stock and consider the information from their close friends and relatives as a reliable reference for their investment decisions.

Mushinada (2020) contended that human beings take risks and make decisions on the basis of their experience, and intuition, instead of gathering relevant information which would encourage them to make better decisions. Shukla et al. (2020) explained that investors' decisions are affected by their information, historical performance, past experiences and expectations. Thus, individual investors tend to demonstrate behavioral biases while trading; therefore, they make trading mistakes.

In any case, the issue is how multiple mediation mechanisms of risk tolerance and financial literacy affect heuristic biases and investment decisions. Studies conducted in Western settings and capitalist-oriented nations cannot be generalized in emerging countries and may not necessarily have any relevance to Tanzanians because of the difference in contextual paradigm.

\subsection{Empirical review and hypothesis development}

2.2.1 Mediation role of financial literacy in overconfidence heuristic and investment decision. Financial literacy is how much one comprehends a key financial idea and has the capacity to make appropriate short-term decision-making and long-range financial planning (Remund, 2010). Individuals are expected to act with overconfidence while considering their own capacities, knowledge and prospects for the future (Parveen et al., 2020). Rasool and Ullah (2019) found a negative association between financial literacy and the behavioral biases of individual investors in Pakistan, implying that with an increase in the degree of financial literacy, the probability of investors confronting behavioral biases diminishes. Ahmad (2020) revealed that investors who are experiencing overconfidence, their trading volume is also high. Therefore, the study hypothesizes:

H1. Financial literacy mediates positively the effect of overconfidence on investment decision.

2.2.2 Mediation role of financial literacy in anchoring heuristic and investment decision. The anchoring heuristic is the one where individuals make their own decisions depending on the initial point (Pompian, 2011). It shows that experts anchor future expectations of stock returns to earlier performance. It further demonstrates that the impact decreases with experience and skill, but does not vanish. As per Awais et al. (2016), a positive sign can make an investor make a good choice. Özen and Ersoy (2019) showed that an increase in the level of financial literacy will decrease heuristic biases in the financial markets. Thus, the following hypothesis is worth pursuing:

H2. Financial literacy mediates negatively the effect of anchoring heuristic on investment decision. 
2.2.3 Mediation role of financial literacy in representativeness heuristic and investment decision. Representativeness occurs when investors' investment choices are always impacted by their easy route and mental stereotypes (Jaiyeoba et al., 2020). Parveen et al. (2020) found that representativeness bias affects individual investors' trading behavior. Ramalakshmi et al. (2019) found that representativeness bias is the primary driver of investors making trading mistakes or poor trading decisions due to lack of financial literacy. They further show that representativeness bias is the reason for investors participating in poor investments due to poor financial knowledge. In this case, it can be hypothesized that:

H3. Financial literacy mediates negatively the effect of representativeness heuristic on investment decision.

2.2.4 Mediation role of financial literacy in availability heuristic and investment decision. Availability heuristics refers to making a decision depending on recently available information Tversky and Kahneman (1974). They further show that investors pick stocks that capture their attention by buying local security rather than foreign security, hence forcing them to look for popular stocks rather than value stocks. Jureviciene and Jermakova (2012) uncovered that the most concerning issue driving an individual to avoid making an investment is a lack of financial knowledge. Consequently, investors who are ignorant of financial literacy, focus on popular stocks which do not give them normal returns over the long term (Rasool and Ullah, 2019). Thus, the study hypothesizes:

H4. Financial literacy mediates negatively the effect of availability heuristic on investment decision.

2.2.5 Mediation role of risk tolerance in overconfidence heuristic and investment decision. Risk is the uncertainty that will be received when making a financial investment (Grable, 2008). Gustafsson and Omark (2015) found that people with risk tolerance have overconfidence. Ahmad (2020) found that risk-takers have higher levels of overconfidence and are more inclined to displaying heuristic biases. He further pointed out that these individuals ignore the updated market information and utilize heuristics based on prior experience. The findings further uncovered that risk-averse individuals follow a systematic decision-making process rather than risk-takers who utilize a heuristic approach. Thus, the following hypothesis is proposed:

H5. Risk tolerance mediates positively the effect of overconfidence on investment decision.

2.2.6 Mediation role of risk tolerance in anchoring heuristic and investment decision. The anchoring heuristic is the tendency to estimate value by imagining the initial value or default number (Pompian, 2011). Anchoring is the human inclination to depend too vigorously on one piece of information when making an investment decision (Andersen, 2010). Previous studies have found that investors adjust stock prices that are most representative of past stock prices, as investors regard past stock prices as anchors to assess future stock prices (Senthamizhselvi and Ram, 2020). Therefore, the following hypothesis is stated:

H6. Risk tolerance mediates positively the effect of anchoring heuristic on investment decision.

2.2.7 Intervening role of risk tolerance in representativeness heuristic and investment decision. Tversky and Kahneman (1974) presented a representativeness heuristic, in which people stick to findings that are more representative. Pak and Mahmood (2015) found that the greater an investor's risk tolerance, the more he would rely on heuristics-based decisions. Most investors overreact to changes in information, consistent with the representativeness
Heuristic biases and investment decision 
$\mathrm{JMB}$

1,2

heuristic (Tversky and Kahneman (1974). In this regard, the representativeness heuristic leads to investors taking too much risk in the stock market. Thus, the study hypothesizes:

H7. Risk tolerance mediates positively the effect of representativeness heuristic on investment decision.

2.2.8 Intervening role of risk tolerance in availability heuristic and investment decision. Tversky and Kahneman (1974) introduced the availability heuristic to explain how easily things come to mind. Investors depend on their past encounters in the market for their next investment decisions (Waweru et al., 2008). Stearns (1977) expresses that the utilization of historical information is not adequately solid to make conclusions. Hence, the availability heuristic prompts investors facing a lot of risk in the stock market. Therefore, the following hypothesis is worth testing:

H8. Risk tolerance mediates positively the effect of availability heuristic on investment decision.

2.2.9 Risk tolerance and investment decision. Risk tolerance has been found to essentially influence investment decision-making in various financial markets (Ishfaq et al., 2020). Grable and Roszkowski (2008) point out that risk tolerance is one of the attributes that are generally required by investors to succeed. Moreover, Samsuri et al. (2019) found that risk tolerance impact positively investment decision. Grable (2016) found that risk-averse individuals invest less in stocks whereby, an individual who has the capacity of high-risk tolerance can invest in more risky stocks to acquire more returns. Thus, investors who are ready to take much risk are ready to purchase stocks (Zeng, 2013). Therefore, the study proposed the following hypothesis:

H9. Risk tolerance is positively related with investment decision.

2.2.10 Financial literacy and investment decision. As per Lusardi and Mitchell (2014), optimal and rational investment decisions rely upon financial knowledge. Jihadi (2018) found a positive effect between financial literacy and investment decisions. Ozen and Ersoy (2019) indicate that the increase in the level of financial literacy of individuals will reduce the cognitive biases and heuristics, and therefore, will have a positive effect on the investor behavior in financial markets. Poor investment decisions happen since people have little investment knowledge (Lusardi and Mitchell, 2007). Likewise, Samsuri et al. (2019) found a positive effect between financial literacy and investment decisions. Therefore, the study hypothesizes:

H10. Financial literacy is positively related with investment decision.

2.2.11 Intervening role of financial literacy in risk tolerance and investment decision. There is an agreement that people who are financially literate will in general be more open-minded toward risk tolerance (Grable and Roszkowski, 2008). As proposed by Grable (2016), if investors know about the degree of risk, they can deal with the circumstances adequately and can acquire more profit. Frijns et al. (2008) found that people who valued themselves as low in terms of financial expertise would, in general, dispense their assets into safer resources. Awais et al. (2016) found that people who are more risk-tolerant are individuals who have more financial knowledge. Reich and Berman (2015) found that less knowledgeable investors are probably going to pick safer investments. Hence, most investigations have found that more financially literate people will be more risk tolerant (i.e. positive relationship) (Niazi and Malik, 2019). Thus, the study hypothesizes:

H11. Financial literacy mediates positively the effect of risk tolerance and investment decision. 
Based on the stated hypotheses, the following hypothetical model (Figure 1) has been developed. It shows that overconfidence, anchoring, representativeness and availability will influence investment decisions when mediated by financial literacy and risk tolerance. Investors who are ready to take a risk are ready to purchase stocks. Also, the increase in the level of financial literacy of individuals will reduce heuristic biases and, therefore, will have a positive effect on investor investment decisions. The objective of this study is to address the following research question:

$R Q 1$. How do heuristic biases when mediated by financial literacy and risk tolerance influence investment decisions in Tanzanian stock market?

\section{Method}

\subsection{Sample and procedure}

This study centers on individual investors and brokers who invest at the Dar es Salaam stock exchange (DSE) in Tanzania. Data were collected face-to-face with the assistance of brokers. The questionnaire was used because the respondents may have very little time for interviews, so the questionnaire was the best strategy since they could finish it at whatever point they have leisure time. The investigation overcame social desirability bias and assured confidentiality (Hair et al., 2006). The process occurred from November, 2020 to March 2021. The questionnaire took almost $30 \mathrm{~min}$ to finish. Respondents were welcome to drop the finished questionnaire in a box which was put at the front counter. This investigation observed anonymity and confidentiality and by having no right or wrong answers, diminished social desirability bias. As per insights obtained from the Dar es Salaam Stock Exchange (DSE) of Tanzania (2020), individual investors represent $40 \%$ of overall investors. Thus, the sample size was acquired by using the following formula (Kothari, 2010):

$$
n=\frac{z^{2} p q}{e^{2}}
$$

Where;

$p=$ sample proportion which is $0.4, q=1-p$

$z=1.96$, the value of the standard variate as per table of area under normal curve for the confidence level of $95 \%$.

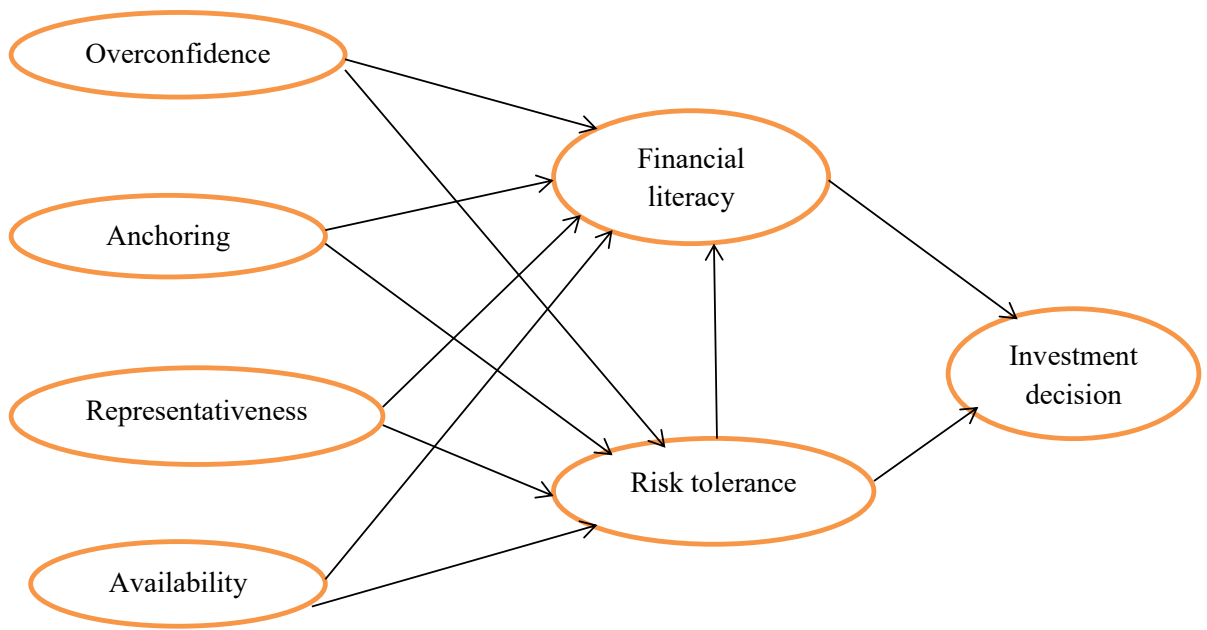

Figure 1. Hypothesized model
Heuristic biases and investment decision 
$\mathrm{JMB}$

1,2

108

The calculation showed approximately the sample size required is 369 respondents. Thus, out of the 369 individual investors targeted, 322 responses were acquired (response rate of $87 \%$ ). After eliminating missing values, the last sample was 316 . The findings show that the majority of respondents were male $(71.5 \%)$. The age of respondents ranged from 18 to greater than 55 years, with the majority aged $36-55$ years $(66.8 \%)$. The majority of the respondents had Bachelor's degrees (43\%), with experience ranging from 1 to 5 years $(63.3 \%)$ ).

\subsection{Measurements}

Three items estimated overconfidence by Babajide and Adetiloye (2012), three items examined representativeness by Waweru et al. (2008), two items estimated anchoring by Babajide and Adetiloye (2012) and four items estimated availability by Waweru et al. (2008). Risk tolerance was estimated by three items chosen from Pasewark and Riley (2010). Financial literacy was estimated by two items chosen from Van Rooji et al. (2011). Two items were utilized to estimate investment decisions selected by Mayfield et al. (2008) and Vlaev et al. (2007). A pre-test was conducted with the assistance of two specialists in finance, an English master and two finance students. They requested that they inspect and evaluate the instruments. Based on their recommendations, corrections were made to the instrument. The responses were measured on 5-point Likert scales $(1=$ "strongly disagree, " 5 = "strongly agree").

\subsection{Data analysis}

To test the hypotheses in the research model, structural equation modeling (SEM) was used, confirmatory factor analysis (CFA) was conducted to determine the quality of the measurement model, followed by convergent and discriminant validity of construct. Then, a structural model was drawn to explore the direct effects of heuristics components on investment decisions. Finally, a multi-mediation of financial literacy and risk tolerance model was constructed to look at the total and specific indirect effects.

\section{Results}

\subsection{Preliminary analysis}

The findings indicate that Kaiser-Meyer-Olkin's (KMO) value was 0.684, which is above the recommended value of 0.5 , suggesting adequacy of the sample size for factor analysis (Sarsted et al., 2019). This was also confirmed by a significant $(\phi<0.001)$ Bartlett's test of sphericity (Hair et al., 2006). Accordingly, factors with loadings above 0.5 and Eigenvalues greater than one were retained (Hair et al., 2006). The results of the factor loading reveal that most of the factors load into component one and a few into components two and three. This was supported by the high values of loadings ranging from 0.5 to 0.9 , indicating a welldefined structure (Hair et al., 2006). Also, the principal component analysis result produced five different factors. Four factors explained $89.69 \%$ of the total variance, while a single factor did not explain the majority of the variance $(6.33 \%)$. Moreover, the common latent factor of all the independent, mediating and dependent variables accounted for $45.06 \%$ of the common factor, which is acceptable because it is less than $50 \%$ of the acceptable criteria. Therefore, common method bias was not a serious issue in the data.

\subsection{Confirmatory factor analysis}

Convergent validity was confirmed by factor loadings. All factor loadings for indicators measuring the same construct were statistically significant $(\phi<0.01)$, supporting convergent validity (Fornell and Larcker, 1981). Accordingly, all variables achieved convergent validity because the average variance extracted (AVE) for all variables was greater than 0.5 , which 
implies that more than $50 \%$ of the variation in the specific variable is due to the specified indicators (Fornell and Larcker, 1981).

The reliability of the measures was confirmed with Cronbach's alpha coefficients $(\alpha)$ higher than the recommended level of 0.7 (Hair et al., 2006), for all constructs. Discriminant validity was confirmed because the square roots of AVE of all variables in the diagonal element were greater than the bivariate correlation of other variables (Fornell and Larcker, 1981) (Table 1). The study used multiple regressing to determine the VIF to test the multicollinearity among the variables. All the variables achieve the minimum criteria for a VIF value of less than 10 (Hair et al., 2006) (Table 4). Therefore, there is no serious problem of multicollinearity.

\subsection{Descriptive statistics}

The results in Table 2 indicate the descriptive statistics of the study variables. The findings show that the level of overconfidence, anchoring, representativeness, availability were high (Mean $=4.557 ; 4.339 ; 4.758$ and 4.883), respectively. These imply that investors depended upon heuristic biases when making investment decision. The level of financial literacy is low (Mean $=2.422$ ), suggesting that investors do not have the skills and knowledge to comprehend key financial ideas. However, the level of risk tolerance was high (Mean $=4.642$ ), suggesting that investors prefer to take risks when it comes to making a financial investment decision. Finally, the level of investment decisions was also high (Mean $=4.639)$, suggesting that if investors received some money, they would invest a certain amount of money in stock markets.

Values of skewness and kurtosis are within the recommended guidelines (Hair et al., 2006). Specifically, values of skewness are neither less than -1 nor more than +1 , and values of kurtosis are neither less than-2 nor more than +2 , implying that there is no concern about non-normal distribution within the sample (Table 2).

\begin{tabular}{|c|c|c|c|c|c|c|c|c|}
\hline Variables & 1 & 2 & 3 & 4 & 5 & 6 & 7 & \\
\hline Overconfidence & 0.902 & & & & & & & \\
\hline Anchoring & $0.483^{* * * *}$ & 0.973 & & & & & & \\
\hline Representativeness & 0.107 & $-0.183^{* * * *}$ & 0.988 & & & & & \\
\hline Availability & $0.410^{* * * *}$ & $0.261^{* * * *}$ & $-0.139 * *$ & 0.981 & & & & \\
\hline Financial literacy & $0.641^{* * * *}$ & $0.484 * * *$ & $0.198^{* * * *}$ & $0.381 * * *$ & 0.973 & & & \\
\hline Risk tolerance & $0.601 * * *$ & $0.195^{* * *}$ & -0.001 & 0.018 & $0.628 * * *$ & 0.939 & & \\
\hline Investment decision & $0.645^{* * * *}$ & $0.329 * * *$ & -0.029 & $0.444^{* * *}$ & $0.605^{* * * *}$ & $0.447 * * *$ & 0.973 & Correlation matrix and \\
\hline \multicolumn{8}{|c|}{ Note(s): $* * * p<0.001 ; * * p<0.05$ (2-tailed) } & discriminant validity \\
\hline
\end{tabular}

\begin{tabular}{|c|c|c|c|c|c|c|c|}
\hline Variables & Mean & $\mathrm{SD}$ & Skew & C.R & Kurtosis & C.R & \\
\hline Overconfidence & 4.557 & 0.479 & -0.195 & -1.416 & -1.893 & -6.868 & \\
\hline Anchoring & 4.339 & 0.474 & 0.682 & 4.950 & -1.535 & -5.569 & \\
\hline Representativeness & 4.758 & 0.422 & -0.194 & -3.664 & -0.537 & -1.950 & \\
\hline Availability & 4.883 & 0.322 & -0.382 & -1.285 & 1.673 & 3.328 & \\
\hline Financial literacy & 2.422 & 0.500 & -0.089 & -0.644 & -1.992 & -7.229 & \\
\hline Risk tolerance & 4.642 & 0.412 & -0.531 & -3.855 & -1.402 & -5.086 & Table 2. \\
\hline Investment decision & 4.639 & 0.481 & -0.580 & -4.208 & -1.664 & -6.037 & Descriptive statistics \\
\hline
\end{tabular}

Heuristic biases and investment decision 
$\mathrm{JMB}$ 1,2

\section{0}

Figure 2.

Structural model

Testing model fit

\subsection{Structural model}

After confirming the soundness of the measures, the study tests the hypothesized relationships through a structural model (Figure 2). The analyses of the goodness-of-fit indices were found to be within the recommended guidelines (Wang and Wang, 2019) (Table 3), hence confirming that the structural model's fit to the data.

\subsection{Hypothesis testing}

The findings of Tables 4 and 5 indicate the direct, indirect and total effects of independent variables on dependent variables. Table 4 shows that financial literacy mediates

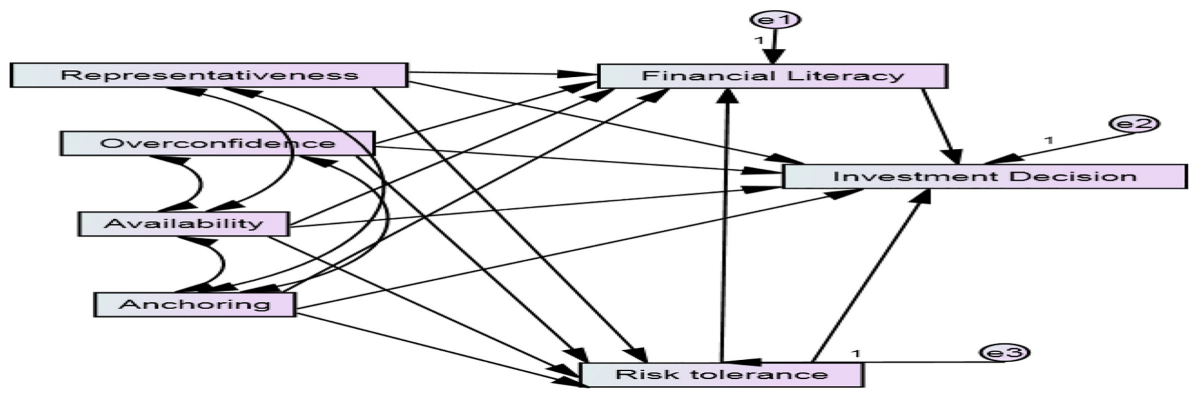

\begin{tabular}{lllllllllll}
$\begin{array}{l}\text { Description of } \\
\text { model }\end{array}$ & CMIN & CFI & TLI & IFI & RFI & GFI & AGFA & NFI & RMR & RMSEA \\
\hline Multi-mediation & $\begin{array}{l}1.494, \mathrm{df}=2 \\
p=0.474 \\
\chi^{2} / \mathrm{df}=0.747\end{array}$ & 1.000 & 1.003 & 1.000 & 0.991 & 0.999 & 0.981 & 0.999 & 0.002 & 0.000 \\
& & & & & & & & & & PCLOSE $=0.693$
\end{tabular}

Note(s): $\chi^{2}$, chi-square; df, degrees of freedom RMR, root mean square residual; GFI, the goodness-of-fit index; AGFI, adjusted goodness-of-fit index; NFI, normed fit index; RFI, relative fit index; IFI, incremental fit index; TLI, Tucker-Lewis index; CFI, comparative fit index; RMSEA, root mean square error of approximation; PCLOSE, parsimony close
Table 4.

Direct and indirect effects of independent variables on dependent variable

\begin{tabular}{|c|c|c|c|c|c|c|c|}
\hline \multirow[b]{2}{*}{$\begin{array}{l}\text { Independent } \\
\text { variable }\end{array}$} & & Direct effec & endent varia & Indire & effects & \multicolumn{2}{|c|}{$\begin{array}{c}\text { Collinearity } \\
\text { statistics }\end{array}$} \\
\hline & $\begin{array}{c}\text { Risk } \\
\text { tolerance }\end{array}$ & $\begin{array}{c}\text { Financial } \\
\text { literacy }\end{array}$ & $\begin{array}{l}\text { Investment } \\
\text { decision }\end{array}$ & $\begin{array}{l}\text { Via risk } \\
\text { tolerance }\end{array}$ & $\begin{array}{l}\text { financial } \\
\text { literacy }\end{array}$ & Tolerance & VIF \\
\hline Overconfidence & $0.807^{* * * *}$ & -0.944 & $0.988^{* * * *}$ & $0.093^{* * * *}$ & -0.084 & 0.629 & 1.591 \\
\hline Anchoring & $0.149^{* * *}$ & -0.053 & $0.151^{\text {**** }}$ & $0.017^{* * * *}$ & -0.016 & 0.711 & 1.407 \\
\hline Representativeness & $0.155^{* * *}$ & -0.109 & $0.118^{* * * *}$ & $0.020^{* * * *}$ & -0.018 & 0.885 & 1.130 \\
\hline Availability & $0.288^{* * * *}$ & -0.001 & $0.073^{* *}$ & $0.051^{* *}$ & -0.031 & 0.798 & 1.253 \\
\hline Financial literacy & & & -0.785 & & & 0.606 & 1.650 \\
\hline Risk tolerance & & $0.104 * * *$ & $0.493^{* *}$ & & -0.211 & 0.606 & 1.650 \\
\hline
\end{tabular}

Note(s): The cell values of table shows the standardized regression weights. *** $p<0.001 ; * * p<0.05$ (2-tailed) 
insignificantly the effect of overconfidence on investment decisions $(\beta=-0.084, p>0.05)$, thus rejecting $\mathrm{H} 1$. The study also rejects $\mathrm{H} 2, \mathrm{H} 3$ and $\mathrm{H} 4$, whereby financial literacy mediates insignificantly the effects of anchoring heuristic $(\beta=-0.016, p>0.05)$, representativeness heuristic $(\beta=-0.018, p>0.05)$ and availability heuristic $(\beta=-0.031, p>0.05)$ on investment decisions, respectively. Further, the results show that risk tolerance mediates positively and significantly the effect of overconfidence on investment decisions $(\beta=0.093, p<0.001)$, thus supporting H5. Also, the study supports H6, H7 and H8, whereby risk tolerance mediates positively and significantly the effects of anchoring heuristic $(\beta=0.017, p<0.001)$, representativeness heuristic $(\beta=0.020, p<0.001)$ and the availability heuristic $(\beta=0.051$, $p<0.05)$ on investment decisions.

Furthermore, the study found a positive and significant effect of risk tolerance on investment decisions $(\beta=0.493, p<0.001)$, supporting H9. The study rejects H10, with an insignificant effect between financial literacy and investment decisions $(\beta=-0.785, p>0.05)$. Also, the findings show that financial literacy mediates insignificantly the effect of risk tolerance on investment decisions $(\beta=-0.211, p>0.05)$, rejecting H11. Moreover, the results show that overconfidence has the highest impact on investment decisions $(\beta=0.898)$, followed by availability $(\beta=0.159)$, representativeness $(\beta=0.157)$, risk tolerance $(\beta=0.147)$, anchoring $(\beta=0.134)$ and finally financial literacy $(\beta=-0.294)$ (see Table 5).

\section{Discussion of findings}

This study analyzes the effect of heuristic biases on investment decision-making by considering the multiple mediation mechanisms of risk tolerance and financial literacy. The results indicate that financial literacy mediates the effect of overconfidence on investment decisions insignificantly. The rejection of $\mathrm{H} 1$ suggests that investors in the Tanzanian stock market do not have enough financial knowledge. However, they trade excessively, confident that they will make a gain. This was supported by the results of Table 5 which show that overconfidence is the largest contributing factor to the investment decision $\beta=0.898$, $p<0.001$ ). Ahmad (2020) found out that investors who are experiencing overconfidence, their trading volume is also high. According to heuristic theory, overconfident investors do excessive trading in the market with the aim of gaining a higher return (Tversky and Kahneman, 1974). As a result, their irrational behavior and overconfidence encourage them to believe that they can gain a higher return, thus investing more in the stock market (Fahim et al., 2019).

The rejection of $\mathrm{H} 2$ suggests that lack of financial literacy encourages the effect of the anchoring heuristic on investment decisions. The findings show that anchoring is one of the contributing factors to the investment decision $(\beta=0.134, p<0.001)$ (Table 5). According to heuristic theory, the review of certain values by considering an initial value and adjusting it upwards or downwards to yield a final judgment is the reason for generating the anchoring heuristic (Tversky and Kahneman, 1974). This hypothesis is consistent with Pompian (2011)

\begin{tabular}{lccc}
\hline & Risk tolerance & Financial literacy & Investment decision \\
\hline Overconfidence & $0.697^{* * *}$ & -0.977 & $0.898^{* * *}$ \\
Anchoring & $0.129^{* *}$ & -0.055 & $0.134^{* * *}$ \\
Representativeness & $0.152^{* * *}$ & -0.127 & $0.157^{* * *}$ \\
Availability & $0.380^{* * *}$ & -0.001 & $0.159^{* *}$ \\
Financial literacy & & & -0.294 \\
Risk tolerance & & $-0.124^{* *}$ & $0.147^{* *}$
\end{tabular}

Note(s): The cell values of table shows the standardized regression weights. ${ }^{* * *} p<0.001 ; * * p<0.05$ (2-tailed)
Heuristic biases and investment decision 
$\mathrm{JMB}$

1,2

who found that the impact of the anchoring heuristic increases with lack of financial knowledge.

The results also indicate that financial literacy mediates insignificantly the effects of representativeness and availability heuristics on investment decisions, rejecting $\mathrm{H} 3$ and $\mathrm{H} 4$. The rejection of H3 implies that lack of financial literacy increases the effects of investors' reliance on the representativeness heuristic. This is consistent with the argument of Ramalakshmi et al. (2019) that representativeness bias increases as the investors lack financial knowledge. The findings of Table 5 show that the representativeness heuristic is also a significant contributing factor to the investment decision $(\beta=-0.157, p<0.001)$. This implies that investors depend on representativeness in stock selection by relying on past performance to buy stocks, because they believe that good performance will continue.

The rejection of $\mathrm{H} 4$ suggests that lack of financial literacy increases the effect of investors considering information from their close friends and relatives as a reliable reference for investment decisions, hence increasing the availability of heuristics. Table 5 also shows that the availability heuristic is the second contributing factor to the investment decision $(\beta=0.159, p<0.05)$. As per heuristic theory, investors tend to heavily weight their decisions toward more recent information (Tversky and Kahneman, 1974). Decisions that rely on heuristics might cause errors in judgment (Tversky and Kahneman, 1974). The result is consistent with the argument of Jureviciene and Jermakova (2012) that financial knowledge is the driving issue for an investor to avoid making errors in investment decisions.

The findings support $\mathrm{H} 5, \mathrm{H} 6, \mathrm{H} 7$ and $\mathrm{H} 8$ that risk tolerance mediates positively and significantly the effects of overconfidence, anchoring, representativeness and availability heuristics on investment decisions, respectively. The support for H5 suggests that overconfident investors tolerate risk, which in turn affects positive investment decisions. This finding concurs with Ahmad (2020) that risk-takers have higher levels of overconfidence and are more inclined to display heuristic biases. Further, the support for H6 suggests that risk-tolerance investors exhibit an anchoring heuristic by depending on the high rate of return achieved in the market before as the benchmark for estimating future return on investment. This is consistent with the argument of Tversky and Kahneman (1974) that investors who are risk-takers associate set prices with past stock prices, thus demonstrating an anchoring heuristic.

The results also confirm $\mathrm{H} 7$, implying that risk-tolerance investors demonstrate a representativeness heuristic by utilizing the past trend analysis of some representative stocks to make investment decisions. Consistent with Pak and Mahmood (2015), the more investors tolerate risk, the greater they depend on heuristics-based decisions. The findings further imply that investors will not behave rationally in all circumstances; sometimes they show opportunistic or irrational behavior in the investment decision-making process. The support for $\mathrm{H} 8$ implies that risk tolerance investors' exhibit availability heuristics by considering easily available information to make investment decisions. This result suggests that, generally, investors do not make rational decisions but base their decisions on irrationality. Similar to the argument of Stearns (1977) that the utilization of historical information is not adequately solid to make conclusions. Consequently, the availability heuristic prompts investors to face a lot of risk in the stock market.

The support for H9 suggests that investors who are ready to take a risk are ready to purchase stocks. This finding concurs with Ishfaq et al. (2020), Samsuri et al. (2019) that risk tolerance influences investment decisions positively. Consistent with Zeng (2013)'s argument that the high-risk level of an investor plays a significant part in deciding a positive investor's decision.

Further, the rejection of $\mathrm{H} 10$ implies that financial literacy is not related to investment decisions. Similarly, the rejection of H11 implies that financial literacy does not influence the effect of risk tolerance and investment decisions. This is supported by the heuristic theory 
that says irrational individuals do not collect all the information; they take some mental easy routes to make their decisions (Tversky and Kahneman, 1974). This happens when investors have imperfect knowledge and they have to make a decision in an uncertain environment without using all of the available information (Jaiyeoba et al., 2020), hence they act irrationally (Jurevièien and Jermakova, 2020). Likewise, Mushinada (2020) found that investors do not have sufficient investment knowledge and skill. Therefore, they used different heuristics in investment decisions.

\section{Conclusion and recommendations}

This study examined the effect of heuristic biases on investment decision-making through multiple mediation mechanisms of risk tolerance and financial literacy in the Tanzanian stock market. Based on the research findings, it can be concluded that financial literacy mediates insignificantly the effect of overconfidence, availability, anchoring and representativeness heuristics on investment decisions. Further, the study shows that financial literacy does not influence the effect of risk tolerance and investment decisions. This implies that investors are irrational; they do not have sufficient investment knowledge and skill. They take risks and use different heuristics in investment decisions. Moreover, risk tolerance is confirmed as a positive mediator of overconfidence, availability, anchoring and representativeness heuristics on investment decisions. This implies that as the tolerance for risk increases, the more investors will depend on heuristics-biases in making investment decisions. Also, the study confirms that investors who are ready to take a risk are ready to purchase stocks. Furthermore, the study shows that overconfidence exerts a stronger influence on investment decisions, followed by availability, representativeness, risk tolerance, anchoring and financial literacy.

This paper contributes to the body of knowledge by using behavioral finance to enhance the understanding of the relationship between heuristic biases and the investment decisions of individual investors, through conceptualizing and conceptualizing multi-mediation processes of risk tolerance and financial literacy in the Tanzanian stock market. The stock market is a mixture of sellers and buyers, in which their irrational behavior affects investment decisions. By examining each component of heuristics separately, the study gain insights that are beneficial to the knowledge of behavioral finance, individual investors and securities institutions. The implications of behavioral finance to the developing stock markets are widely applied. However, the application of behavioral finance to the emerging stock markets like Tanzania has been limited. Therefore, individual investors can analyze and evaluate their behavior toward stock selection. Securities institutions can use this research to understand investors' behavior, evaluate future market trends and provide advice to the investors.

Future research should confirm the findings of this research in other contexts and consider other factors of heuristic biases such as conservatism, gambler fallacy and illusion of control, which could have significant influences on stock market investment decisions. Second, the study deals with real investors. Further research could examine the effects of heuristic biases on investment decisions by adding or modifying the items of particular constructs and studying institutional investors.

\section{References}

Abdin, Z.S., Farooq, O., Sultana, N. and Farooq, M. (2017), "The impact of heuristics on investment decision and performance: exploring multiple mediation mechanisms", Research in International Business and Finance, Vol. 42 No. 1, pp. 674-688.

Ahmad, F. (2020), "Personality traits as predictor of cognitive biases: moderating role of risk-attitude", Qualitative Research in Financial Markets, Vol. 12 No. 4, pp. 465-484. 
JMB 1,2

Ahmad, M. (2020), "Does underconfidence matter in short-term and long-term investment decisions? Evidence from an emerging market”, Management Decision, Vol. 59 No. 3, pp. 692-709.

Andersen, J.V. (2010), "Detecting anchoring in financial markets", Journal of Behavioral Finance, Vol. 11 No. 2, pp. 129-133.

Asad, H., Khan, A. and Rafia Faiz, R. (2018), "Behavioral biases across the stock market investors: evidence from Pakistan”, Pakistan Economic and Social Review, Vol. 56 No. 1, pp. 185-209.

Awais, M., Laber, F.M., Rasheed, N. and Khursheed, A. (2016), "Impact of financial literacy and investment experience on risk tolerance and investment decisions: empirical evidence from Pakistan”, International Journal of Economics and Financial Issues, Vol. 6 No. 1, pp. 73-79.

Babajide, A.A. and Adetiloye, K.A. (2012), "Investors' behavioural biases and the security market: an empirical study of the Nigerian security market", Accounting and Finance, Vol. 1 No. 1, pp. 219-229.

DSE (2020), Dar Es Salaam Stock Exchange Annual Report, Dar es Salaam, Tanzania, available at: https://www.dse.co.tz/content/2020-dse-annual-report.

Fahim, F., Ali, A., Khan, A.M. and Khan, A.R. (2019), "Impact of overconfidence on investor's investment decision: moderating role of risk perception and religiosity-A survey of Pakistan stock exchange", JISR-MSSE, Vol. 17 No. 2, pp. 85-96.

Fornell, C. and Larcker, D.F. (1981), "Evaluating structural equation models with unobservable variables and measurement error", Journal of Marketing Research, Vol. 18 No. 1, pp. 39-50, doi: $10.2307 / 3151312$.

Frijns, B., Koellen, E. and Lehnert, T. (2008), "On the determinants of portfolio choice", Journal of Economic Behavior and Organization, Vol. 66 No. 2, pp. 373-386.

Grable, J.E. (2008), "Risk tolerance", in Xiao, J.J. (Ed.), Advances in Consumer Financial Behavior Research, Springer, New York, NY, pp. 1-20.

Grable, J.E. (2016), "Financial risk tolerance", in Xiao, J. (Ed.), Handbook of Consumer Finance Research, Springer, Cham, pp. 19-31.

Grable, J.E. and Roszkowski, M.J. (2008), "The influence of mood on the willingness to take financial risks", Journal of Risk Research, Vol. 11 No. 7, pp. 905-923.

Gustafsson, C. and Omark, L. (2015), "Financial Literacy's Effect on Financial Risk Tolerance”, a Degree Project, School of Business and Economics, Umea University, Umea.

Hair, J.F., Black, W.C., Babin, B.J., Anderson, R.E. and Tatham, R.L. (2006), Multivariate Data Analysis, Pearson Prentice Hall, Upper Saddle River, New Jerssey, NJ, Vol. 6.

Hvide, H.K. (2002), "Pragmatic beliefs and overconfidence", Journal of Economic Behavior and Organization, Vol. 48 No. 1, pp. 15-28.

Ishfaq, M., Nazir, M.S., Qamar, M.A.J. and Usman, M. (2020), "Cognitive bias and the extraversion personality shaping the behavior of investors", Frontier in Psychology, Vol. 11 No. 1, pp. 1-11.

Jaiyeoba, B.H., Abdullah, A.M. and Ibrahim, K. (2020), "Institutional investors vs retail investors: are psychological biases equally applicable to investor divides in Malaysia", International Journal of Bank Marketing, Vol. 38 No. 3, pp. 671-691.

Jihadi, M. (2018), Financial Literacy, Attitude, Subjective Norms, Perceived Behavior Control and Intention to Invest, Dissertation, Economic and Business Faculty of Airlangga University, Surabaya.

Jureviciene, D. and Jermakova, K. (2012), "The impact of individuals financial behaviour on investment decisions", Electronic International Interdisciplinary Conference, pp. 242-250, available at: http://www.eiic.cz.

Kothari, R.C. (2010), Research Methodology: Methods and Techniques, 4th ed., New Age International (P) Publishers, New Delhi. 
Lusardi, A. and Mitchell, O.S. (2014), "The economic importance of financial literacy: theory and evidence", Journal of Economic Literature, Vol. 52 No. 1, pp. 5-44.

Lusardi, A. and Mitchelli, O.S. (2007), "Financial literacy and retirement preparedness: evidence and implications for financial education”, Business Economics, Vol. 42 No. 1, pp. 35-44.

Mayfield, C., Perdue, G. and Wooten, K. (2008), "Investment management and personality type", Financial Services Review, Vol. 17 No. 3, pp. 219-236.

Mushinada, C.N.V. (2020), “Are individual investors irrational or adaptive to market dynamics?", Journal of Behavioral and Experimental Finance, Vol. 25 No. 1, pp. 1-8.

Niazi, S.K.M. and Malik, A.Q. (2019), "Financial attitude and investment decision making - moderating role of financial literacy”, International Journal of Business and Management, Vol. 14 No. 1, pp. 102-115.

Özen, E. and Ersoy, G. (2019), "The impact of financial literacy on cognitive biases of individual investors", Contemporary Studies in Economic and Financial Analysis, Vol. 101 No. 1, pp. 77-95.

Pak, O. and Mahmood, M. (2015), "Impact of personality on risk tolerance and investment decisions: a study on potential investors of Kazakhstan", International Journal of Commerce and Management, Vol. 25 No. 4, pp. 370-384.

Parveen, S., Satti, W.Z., Subhan, A.Q. and Jamil, S. (2020), “Exploring market overreaction, investors' sentiments and investment decisions in an emerging stock market", Borsa Istanbul Review, Vol. 20 No. 3, pp. 224-235.

Pasewark, W.R. and Riley, M.E. (2010), "It's a matter of principle: the role of personal values in investment decisions", Journal of Business Ethics, Vol. 93, pp. 237-253.

Peloza, J. (2009), "The challenge of measuring financial impacts from investments in corporate social performance", Journal of Management, Vol. 35 No. 6, pp. 1518-1541, doi: 10.1177/0149206309335188.

Pompian, M.M. (2011), Behavioral Finance and Wealth Management: How to Build Optimal Portfolios that Account for Investor Biases, John Wiley \& Sons, Vol. 667.

Raheja, S. and Dhiman, B. (2020), "How do emotional intelligence and behavioral biases of investors determine their investment decisions?”, Rajagiri Management Journal, Vol. 14 No. 1, pp. 35-47.

Ramalakshmi, V., Pathak, K.V., Jos, M.C. and Baiju, E. (2019), "Impact of cognitive biases on investment decision making", Journal of Critical Reviews, Vol. 6 No. 6, pp. 59-66.

Rasool, N. and Ullah, S. (2019), "Financial literacy and behavioural biases of individual investors: empirical evidence of Pakistan stock exchange", Journal of Economics, Finance and Administrative Science, Vol. 25 No. 50, pp. 261-278.

Reich, C.M. and Berman, J.S. (2015), "Do financial literacy classes help? An experimental assessment in a low-income population”, Journal of Social Service Research, Vol. 41 No. 2, pp. 193-203.

Remund, D.L. (2010), "Financial literacy explicated: the case for a clearer definition in an increasingly complex economy", Journal of Consumer Affairs, Vol. 44 No. 2, pp. 276-295.

Ritter, J.R. (1988), "The buying and selling behavior of individual investors at the turn of the year", Journal of Finance, Vol. 43 No. 3, pp. 701-717.

Samsuria, A., Ismiyantib, F. and Narsa, M.I. (2019), "Effects of risk tolerance and financial literacy to investment intentions", International Journal of Innovation, Creativity and Change, Vol. 10 No. 9 , pp. 40-54.

Sarsted, M., Hair, J.F. Jr, Cheah, J.H., Becker, J.M. and Ringle, C.M. (2019), "How to specify, estimate, and validate higher-order constructs in PLS-SEM", Australasian Marketing Journal, Vol. 27 No. 3, pp. 197-211.

Senthamizhselvi, A. and Ram, S.V. (2020), "Role of behavioural finance in portfolio selection and investment decision-making", Journal of Critical Reviews, Vol. 7 No. 12, pp. 320-329.

Shayo, H. (2020), Why Tanzania Stock Market Grows at Slow Pace?, Tanzania Daily News, Dar es Salaam, Tanzania.
Heuristic biases and investment decision 
$\mathrm{JMB}$

1,2

Shukla, A., Rushdi, J.N. and Katiyar, C.R. (2020), "Impact of behavioral biases on investment decisions: a systematic review", International Journal of Management, Vol. 11 No. 4, pp. 68-76.

Stearns, S.C. (1977), "The evolution of life history traits: a critique of the theory and a review of the data", Annual Review of Ecology, Evolution, and Systematics, Vol. 8 No. 1, pp. 145-171.

Tversky, A. and Kahneman, D. (1974), "Judgment under uncertainty: heuristics and biases”, Science, Vol. 185 No. 4157, pp. 1124-1131.

Van Rooij, M., Lusardi, A. and Alessie, R. (2011), "Financial literacy and stock market participation", Journal of Financial Economics, Vol. 101 No. 2, pp. 449-472.

Vlaev, I., Chater, N. and Stewart, N. (2007), "Financial prospect relativity: context effects in financial decision-making under risk", Journal of Behavioral Decision Making, Vol. 20 No. 3, pp. 273-304.

Wang, J. and Wang, X. (2019), Structural Equation Modeling: Applications Using Mplus, 2nd ed., Wiley Series in Probability and Statistics, Wiley.

Waweru, N.M., Munyoki, E. and Uliana, E. (2008), "The effects of behavioural factors in investment decision-making: a survey of institutional investors operating at the Nairobi stock exchange", International Journal of Business Emerging Market, Vol. 1 No. 1, pp. 24-41.

Zeng, Y. (2013), The Development of the Risky Financial Behavior Scale: A Measure of Financial Risk Tolerance, Morgridge College of Education, University of Denver, Colorado.

Ziorklui, (2001), "The development of capital markets and growth in Sub-Saharan Africa: the case of Tanzania", African Economic Policy Discussion Paper Number 79, Washington, District of Columbia, pp. 1-54.

\section{Further reading}

CMSA (2007), Business and Institutional Strengthening Plan for the Period 2007/8 to 2011/12, Dar es Salaam, Tanzania.

Dangol, J. and Manandhar, R. (2020), "Impact of heuristics on investment decisions: the moderating role of locus of control", Journal of Business and Social Sciences, Vol. 5 No. 1, pp. 1-14.

Grable, J. (2000), "Financial risk tolerance and additional factors that affect risk taking in everyday money matters", Journal of Business and Psychology, Vol. 14 No. 4, pp. 625-630.

Grable, J.E. and Joo, S.H. (1999), "Factors related to risk tolerance: a further examination", Consumer Interests Annual, Vol. 45, pp. 53-58.

\section{Corresponding author}

Pendo Shukrani Kasoga can be contacted at: pendo.kasoga@udom.ac.tz

For instructions on how to order reprints of this article, please visit our website:

www.emeraldgrouppublishing.com/licensing/reprints.htm

Or contact us for further details: permissions@emeraldinsight.com 